\title{
Analisis Wawasan Jender Perempuan pada Perspektif Keluarga
}

\author{
Sumiharti*, Sainil Amral \\ FKIP Universitas Batanghari \\ Jl. Slamet Ryadi, Broni-Jambi \\ *Correspondence email: harti.sumi6565@gmail.com, amralsainil@gmail.com
}

\begin{abstract}
Abstrak. Tujuan penelitian ini untuk mendeskripsikan wawasan jender perempuan pada perspektif keluarga melalui struktur penokohan dalam novel Atap karya Fira Basuki. Penelitian ini menggunakan metode penelitian deskriptif kualitatif, memecahkan masalah dalam sebuah penelitian dengan menggambarkan atau melukiskan dan menginterpretasi objek yang berupa gejala atau kejadian sosial yang terungkap melalui ungkapan. Melalui penelitian ini, peneliti dapat mendeskripsikan data-data dari objek penelitian yang berhubungan dengan aspek-aspek wawasan jender perempuan pada perspektif keluarga melalui struktur penokohan dalam novel Atap karya Fira Basuki. Aspek tersebut terdiri dari aspek perubahan sosial budaya melalui keluarga dan aspek kekerasan dalam keluarga dari sudut pandang feminis. Sumber data dalam penelitian ini adalah novel Atap karya Fira Basuki. Data dalam penelitian ini diperoleh dari kata, kalimat, atau ungkapan yang terdapat dalam novel yang mengacu pada aspek aspek perubahan sosial budaya melalui keluarga dan aspek kekerasan dalam keluarga dari sudut pandang feminis. Hasil penelitian menunjukkan bahwa pada perubahan sosial budaya melalui keluarga ditemukan bahwa masih terdapat bias jender terhadap keadilan yang didapat oleh kaum perempuan. Bias jender juga ditemukan pada tokoh perempuan Kunti, Jane dan dan Mak Umah akibat dari kekerasan dalam keluarga dari sudut pandang feminis. Berdasarkan Permasalahan yang timbul dalam hubungan sosial budaya melalui keluarga sebaiknya disikapi dengan bijak dan diarah dalam bentuk perlindungan. Contohnya dibuat perlindungan hukum dan masyarakat memahami bentuk perlindungan hukum yang ada.
\end{abstract}

Kata Kunci: analisis; wawasan jender; perempuan; novel

Abstract. The purpose of this research is to describe women's gender insight from a family perspective through the characterization structure in Fira Basuki's novel Atap. This research uses descriptive qualitative research methods, solving problems in a study by describing or interpreting objects in the form of social phenomena or events that are revealed through expressions. Through this research, researchers can describe data from the object of research related to aspects of women's gender insight from a family perspective through the characterization structure in Fira Basuki's novel Atap. These aspects consist of aspects of socio-cultural change through the family and aspects of violence in the family from a feminist point of view. The source of data in this reseaech is the novel Atap by Fira Basuki. The data in this research were obtained from words, sentences, or expressions contained in the novel which refer to aspects of socio-cultural change through the family and aspects of family violence from a feminist point of view. The results showed that in socio-cultural changes through the family, it was found that there was still a gender bias towards justice that was obtained by women. Gender bias is also found in the female characters Kunti, Jane and Mak Umah as a result of violence in the family from a feminist point of view. Based on the problems that arise in socio-cultural relations through the family, it should be addressed wisely and directed in the form of protection. For example, legal protection is made and the public understands the existing forms of legal protection.

Keywords: analysis; gender insight; women; novel

\section{PENDAHULUAN}

Karya sastra merupakan karya yang mampu membuat manusia menjadi lebih kreatif. Karya sastra juga merupakan suatu wadah untuk mengungkapkan gagasan, ide, dan pikiran dengan gambaran-gambaran pengalaman. Selanjutnya, karya sastra merupakan karya yang menjadikan manusia mampu menuangkan segala cerita di dalam tulisan dengan menggunakan cerita-cerita kehidupan dengan berbagai macam persoalan kehidupan yang ada di masyarakat. Menurut Wicaksono (2014), karya sastra adalah bentuk kreativitas dalam Bahasa yang berisi sederetan pengalaman batin dan imajinasi yang berasal dari penghayatan atas realitas-nonrealitas sastrawannya. Karya sastra memiliki fungsi atau manfaat yang baik bagi pembaca. Menurut Kosasih (2008) karya sastra memiliki fungsi atau manfaat yang baik, yaitu fungsi rekreatif dan fungsi didaktif.
Dalam masyarakat yang sedang mengalami perubahan nilai, keluarga sebagai pusat penerus nilai dituntut untuk meneruskan nilai-nlai lama yang perlu dilestarikan dan aktif memperkenalkan nilai-nilai baru yang dianggap baik. Sesuai perkembangan zaman, Hal ini dapat terjadi pada perempuan yang meninggalkan suaminya untuk bekerja, konflik akan terjadi jika keluarga atau suami tidak memberi izin untuk bekerja. Di sinilah peran jender sangat dibutuhkan.

Menurut Ann Oskley dalam Baidawi (2001), jender adalah sifat laki-laki dan perempuan yang dikonstruksi secara sosial dan kultural sehingga tidak identik dengan seks. Sementara itu, menurut Puspitawati (2012) jender adalah perbedaan jenis kelamin antara laki-laki dan perempuan dalam peran, fungsi, hak, tanggung jawab, dan perilaku yang dibentuk oleh tata nilai sosial, budaya dan adat istiadat dari kelompok 
masyarakat yang dapat berubah menurut waktu serta kondisi setempat. Selaras dengan itu, analisis jender digunakan untuk mengkaji dengan mendalam ketimpangan peran, fungsi, dan hubungan diantara lakilaki dan perempuan.

Selaras dengan itu, analisis gender digunakan untuk mengkaji dengan mendalam ketimpangan peranan, fungsi dan hubungan di antara lelaki dan Wanita (Mufidah, 2004).Timbulnya paradigma tentang jender tidak terlepas dari sikap dan perilaku deskriminasi kaum laki-laki terhadap kaum perempuan. Padahal perempuan diciptakan untuk menjadi pasangan atau teman laki-laki, bukan untuk disakiti dan diperlakukan tidak adil. Tak dapat dipungkiri, perempuan di zaman sekarang pun masih banyak yang mengalami pelecehan dan kekerasan fisik.

Perempuan dalam perspektif keluarga pada aspek perubahan sosial budaya melalui keluarga menurut Mosse (1996) adalah hubungan antara laki-laki dan perempuan sering kali amat penting dalam menentukan posisi keduanya. Hal ini tentu saja untuk menghindari hal-hal yang buruk yang sangat tidak diinginkan. Misalnya, hubungan dalam kuluarga yang dikonstruksikan vertikal dirubah menjadi hubungan yang horizontal.

Perempuan dalam perspektif keluarga pada aspek kekerasan dalam keluarga dari sudut pandang feminis menurut Murniati (2004) mengacu pada pengalaman laki-laki dan perempuan dalam keluarga adalah berbeda, sehingga diharapkan keluarga dapat mengoreksi kesalahan ideologi jender yang mengotakkan jenis manusia. Jadi, sesungguhnya bebas dari kekerasan menjadi isu kunci bagi kelompok perempuan di seluruh dunia dari sudut pandang feminis.

Feminisme merupakan gerakan perempuan yang dipicu oleh adanya kesadaran bahwa hak-hak perempuan sama dengan laki-laki, hal ini menuntut kemandirian perempuan untuk melakukan sesuatu. "Feminisme berangkat dari asumsi bahwa perempuan pada dasarnya ditindas dan dieksploitasi" Faqih (2001). Sedangkan menurut Wolf (1994) feminisme sebagai sebuah teori yang mengungkapkan harga diri pribadi dan harga diri semua perempuan.

Novel adalah karya sastra yang bersifat imajinatif yang di dalamnya terdapat masalah kehidupan seseorang atau beberapa tokoh. "Novel adalah karya imajinatif yang mengisahkan sisi utuh problematika kehidupan seseorang atau beberapa tokoh" (Kosasih, 2012). Berdasarkan pendapat ahli ini, novel merupakan hasil dari imajinasi pengarang mengenai permasalahan kehidupan yang dialami oleh seseorang atau beberapa tokoh.

\section{METODE}

Pendekatan penelitian yang digunakan adalah pendekatan kualitatif dengan metode deksriptif. Penelitian kualitatif merupakan jenis penelitian yang mengutamakan kata-kata bukan angka-angka dalam menganalisis data. "Penelitian kualitatif adalah penelitian yang menghasilkan prosedur analisis yang tidak menggunakan prosedur analisis statistik atau cara kuantifikasi lainnya" (Moleong, 2018). Sedangkan metode deskriptif merupakan metode yang bertujuan mendeskripsikan suatu fenomena secara akurat. "Penelitian deskriptif juga bererti penelitian yang dimaksudkan untuk menjelaskan fenomena atau karakteristik individual, situasi, atau kelompok tertentu secara akurat" (Danim, 2002).

Sumber data dalam penelitian ini adalah novel Atap karya Fira Basuki Terbitan tahun 2003. Data dalam penelitian ini diperoleh dari kata, kalimat, atau ungkapan yang terdapat dalam novel yang mengacu pada aspekaspek perubahan sosial budaya melalui keluarga dan aspek kekerasan dalam keluarga dari sudut pandang feminis.

\section{HASIL DAN PEMBAHASAN}

Persoalan bagi manusia yang bertanggung jawab adalah mengubah dunia ini menjadi lebih baik, lebih adil, dan lebih damai. Oleh karena itu, untuk mewujudkan hal ini pada skala besar yang mengarah pada sosial budaya, harus dibangun melalui keluarga berdasarkan pada kesetaraan jender yang lebih adil. Perbedaan antara perempuan dan laki-laki dalam berbagai persoalan hendaknya didialogkan tanpa ada yang memaksakan kehendak terhadap situasi dunia yang semakin tidak adil karena ukah manusia. Walau bagaimanapun, demokrasi akan menciptakan keadilan, dan keadilan pada akhirnya akan menciptakan sebuah keluarga yang damai dan bahagia.

Melalui penelitian ini diperoleh hasil bahwa kesatuan sosial terkecil dalam kehidupan masyarakat adalah keluarga. Keluarga memiliki peranan yang sangat penting karena di dalam sebuah keluarga berlangsung proses sosialisasi yang akan berpengaruh besar terhadap tumbuh dan berkembangnya setiap individu baik secara fisik, mental, maupun sosial agar tercapai kehidupan yang aman dan sejahtera. Untuk mencapai kehidupan yang aman dan sejahtera harus jauh dari persoalan ketidakadilan. Terutama ketidakadilan terhadap individu berjenis kelamin laki-laki maupun berjenis kelamin perempuan. Hasil penelitian menunjukkan bahwa:

\section{Perubahan Sosial Budaya Melalui Keluarga}

Pada perubahan sosial budaya melalui keluarga ditemukan bahwa masih terdapat bias jender terhadap keadilan yang didapat oleh kaum perempuan, antara lain peristiwa poligami, yang dilakukan Bowo terhadap Aida, istri pertamanya. Ketidakadilan ini diterima Aida dengan menahan hati dan perasaan sehingga perbuatan ini juga tidak didukung oleh keluarga Bowo, terutama adiknya yang bernama June. Secara sosial budaya, poligami dapat menyebabkan kaum pertempuan merasa tersakiti sehingga muncullah persoalan ketidakadilan yang 
menyebabkan perempuan tersakiti sehingga terjadi bias jender. Hal ini mengacu pada pandangan kaum feminis yang melarang keras poligami yang berangkat dari isu utama feminisme bahwa perempuan adalah manusia yang sejajar dengan laki-laki yang berhak mendapat tempat yang sama dengan laki-laki baik dalan bidang sosial maupun budaya, dalam hal ini terkait dengan keluarga dan rumah tangga. Hal ini sejalan dengan pendapat Mufidah (2004) bahwa timbulnya paradigma tentang jender tidak terlepas dari sikap dan perilaku deskriminasi kaum laki-laki terhadap kaum perempuan. Padahal perempuan diciptakan untuk menjadi pasangan atau teman laki-laki, bukan untuk disakiti dan diperlakukan tidak adil.

Selanjutnya, ditemukan juga bias jender dalam persoalan kepercayaan terhadap pasangan hidup dalam berkeluarga. Kepercayaan berlibur yang sudah diberikan Jigme kepada istrinya June ternyata disalahgunakan June. Ternyata June pergi berlibur menemui mantan pacarnya yang bernama Aji Saka. Perlakuan ini tentu saja dapat menimbulkan kemarahan besar suami kepada istri sehingga kehidupan yang sejahtera dan harmonis dalam berkeluarga tidak tercapai.

\section{Kekerasan dalam Keluarga Dari Sudut Pandang Feminis}

Hasil temuan pada kekerasan dalam keluarga dari sudut pandang feminis mengacu pada kekerasan kaum laki-laki terhadap kaum perempuan, dalam hal ini kekerasan suami terhadap istri yang mengakibatkan perempuan tidak memiliki harga diri sesuai dengan pendapat Wolf (1994). Kita ketahui, feminisme merupakan gerakan perempuan yang dipicu oleh adanya kesadaran bahwa hak-hak perempuan sama dengan lakilaki, hal ini menuntut kemandirian perempuan untuk melakukan sesuatu. Kekerasan fisik terhadap perempuan mampu menjadi permasalahan serius dikalangan masyarakat. Kekerasan terhadap perempuan merupakan refleksi dari banyaknya ketidakadilan gender yang ada di masyarakat seperti tindakan pemukulan dan pelecehan seksual terhadap perempuan. Hal tersebut menempatkan perempuan berada diurutan nomor dua setelah laki-laki.

Sistem yang menempatkan laki-laki sebagai pemimpin tersebut menjadikan laki-laki merasa lebih kuat dari perempuan, dan kekerasan yang terjadi oleh suatu jenis kelamin tertentu disebabkan oleh bias jender. Hal ini ditemukan pada tokoh perempuan Kunti, Jane dan dan Mak Umah. Tokoh ini sama-sama memiliki pengalaman pahit dipukul oleh suami sehingga mereka mengambil sikap untuk meninggalkan suaminya. Jika perbuatan kekerasan ini dipertahankan maka akan terjadi ketidakadilan yang mengakibatkan kaum perempuan tersakiti dan trauma dalam membina rumah tangga. Hal ini seharusnya tidak boleh dilakukan mengingat kekerasan bukanlah jalan terbaik untuk menyelesaikan masalah, terutama masalah rumah tangga.

\section{Pembahasan}

Analisis penokohan yang membahas wawasan jender perempuan dalam perspektif keluarga pada novel Atap dapat adalah sebagai berikut:

\section{Perubahan Sosial Budaya melalui Keluarga}

Untuk melukiskan watak tokoh June secara langsung, maka digunakanlah analisis penokohan. June sebagai perempuan yang tidak berkenan dengan sikap Putri sebagai sesama perempuan yang ingin menikah dengan lelaki yang sudah memiliki istri dapat dilihat pada kutipan berikut:

Manusia itu berubah sejalan dengan waktu. Mas Bowo berubah, tentu saja. Mas sudah memiliki mbak Ida. Namun bukan itu saja, kini mas memiliki ide gila yang lain: menyunting Putri.

Bagaimana bisa? Bagaimana bisa seorang pria jatuh cinta seenak udelnya sendiri dan kemudian menyatakannya? Lebih parah, mengapa perempuan begitu mudah takluk pada pria.

Aku benci sitem kehidupan, dimana pihak perempuan walaupun katanya memiliki hak azazi yang sama ternyata tidak berdaya pada cinta pria. Sekuat apa pun seorang perempuan, mengapa tidak bisa berdiri kukuh di kedua kakinya sendiri? Mengapa harus bertemu pria dan menikahinya? Lebih parah, pun jika si pria sudah menikah (A, 2003: 12).

Dari gambaran kutipan di atas dapat dilihat bahwa sebagai seorang perempuan June turut merasakan ketidakadilan yang akan terjadi pada rumah tangga kakaknya Bowo dan Aida apa bila Bowo menikah lagi dengan perempuan lain. Ketidakadilan itu jelas dapat menimbulkan korban di pihak perempuan yang menyebabkan keutuhan rumah tangga akan terganggu. Hal ini diperkuat dengan kutipan berikut:

Aku terpana. Bagaimana bisa seorang pria berbagi cinta secara adil? Bagaimana nasib mbak Aida? Mas Bowo adalah Masku, sedangkan Putri di hati tetaplah kawanku. Kudekati Mbak. Matanya redup, diam, dan kemudian tersenyum miris (A, 2003: 13).

Sebagai dampak dari konstruksi sosial budaya, permasalahan tersebut di atas tentu saja merupakan permasalahan yang terjadi dalam kehidupan manusia. Pendirian tegas June terhadap keadilan tidak mampu mengubah pendirian Bowo untuk menikahi Putri. Apa lagi sebagai perempuan, Aida istrinya hanya menurut saja walau hatinya tersakiti. Proses yang tidak menyebabkan pertikaian dan sadar jender tersebut dapat dilihat melalui kutipan berikut:

Aku terempas. Bagaimana lagi jika yang bersangkut paut tidak menolak? Bagaimana bisa aku yang di luar pagar masuk? Mas Bowo akhirnya jadi 
menikahi Putri setelah mengantongi surat izin dari Mbak Aida. Aku, Mama, dan Papa hadir tanpa emosi yang pasti A, 2003: 13).

Sementara itu, untuk melukiskan tokoh June yang memiliki keluarga yang berangkat dari perubahan sosial budaya melalui keluarga berdasarkan kesetaraan jender yang lebih adil tampak dari kepergian June berlibur atas izin suami Jigme dan tanpa memaksakan kehendak. Hal ini dapat dilihat melalui kutipan berikut:

Aku diam saja. Natal dan tahun baru, atau kapan saja rasanya hari-hari biasa untukku dan Jigme. Lagi pula, bukankah ia yang menyuruhku dating ke sini? (A, 2003: 138).

Dari kutipan di atas tergambar jelas bahwa selama tidak ada pertikaian dan ketidakadilan di dalam rumah tangga maka proses jender sudah dilaksanakan. Sang suami dengan ikhlas mengizinkan istrinya berlibur agar terhindar dari kejenuhannya sehari-hari mengurus rumah tangga.

Untuk memperlihatkan sikap June yang telah berubah akibat situasi dunia yang semakin tidak adil karena hubungan antara laki-laki dan perempuan yang telah rusak akibat dari konstruksi sosial budaya melalui keluarga tergambar pada kutipan berikut:

Aku tidak pernah tahu makna cinta, karena itu aku mencarinya. Ya Gusti, apakah ini artinya cinta? Mungkin ya baginya. Dalam dan luar tubuhnya mengalir untukku. Ia pernah gila, ia pernah jatuh, namun kini waras dan bangun. Benarkah ia menungguku? Mengapa ia tahu aku akan Kembali? Kalau tidak, mengapa aku jauh-jauh datang sekedar ingin melihatnya? Apakah cinta dihitung dari pengorbanan? Jigme yang mengikutiku dan Aji yang menungguku? Ataukah pemujaan---seperti Mr. X? (A, 2003: 157).

Gambaran kutipan di atas menunjukkan bahwa sebagai seorang perempuan yang masih memiliki suami, June terjerat pada perubahan sosial budaya melalui keluarga karena sesungguhnya June sudah menikah namun ia merasa belum menemukan arti cinta dalam kehidupan rumah tangganya. Dengan rasa kebimbangan itulah ia mencoba menemui mantan pacarnya yaitu Aji Saka. Lama June menyesuaikan diri dengan Aji Saka, namun ia tetap merasa tidak cocok. Akhirnya ia memilih untuk Kembali kepada suaminya Jigme sehingga hubungan keluarga mereka berjalan penuh kedamaian.

Penokohan melalui reaksi tokoh pada aspek perubahan sosial budaya melalui keluarga ditemukan pada saat Jane, seorang pembantu rumah tangga pada keluarja Aji Saka mengingatkan June pada suaminya Jigme karena di mata Jane terbersit kesan bahwa June tampaknya tidak bahagia. Melalui penokohan ini digambarkan bahwa selama ini June telah berbuat salah terhadap keluarganya karena ia pergi untuk menemui pacarnya. Namun, melalui tokoh Jane, barulah June sadar bahwa ia telah memiliki suami. Rentetan sindiran kata-kata yang keluar dari mulut Jane membuat June mulai memikirkan suaminya. Hal ini menunjukkan bahwa proses jender berjalan karena terjadi perubahan tokoh June yang menyadari dan bertanggungjawag terhadap situasi yang tidak adil. Peristiwa ini terdapat dalam kutipan berikut:

"Kamu tidak Bahagia," begitu kata Jane mengulang kata batinku. Aku terdiam saja, sambal pura-pura membaca puisi "Maya Angelau" hadiah dari Mr. Sone.

"Hatimu bertolak bukan? Motel ini bukan sumber hebahagiaanmu dan juga bukan Aji Saka."

Aku mulai tertarik kata-kata Jane. "Maksudmu?"

Jane menghentikan kegiatannya Menyusun cangkir. "Maksudku, Aji mencintaimu. Sedangkan kamu bingung. Kamu tidak tahu mencintainya atau tidak, Jika ya, apalah arti cinta bagimu? Mengapa kamu tampak tidak bahagia?"

"Lalu suamimu bagaimana?"

Sudah lama tidak yang menyebut nama suamiku. Bahwa aku bersuami. Kulihat jariku, cincin itu masih di sana (A, 2003: 176).

Selain itu, untuk memperlihatkan sikap June sebagai perempuan yang sudah sadar dengan segala kekeliruan dari perubahan budaya melalui keluarga untuk mencapai kedamaian dan keadilan di rumah tangga Bersama sang suami dapat dilihat pada kutipan beriku:

"Syukurlah jika kamu sudah sdar June."

"Ya, Mas. Aku sungguh beruntung punya suami Jigme. Bukankah orang mencari cinta itu untuk ketenangan jiwanya? Aku sekarang merasa di rumah Bersama Jigme."

"Kamuy akin?"

"Iyalah Mas. Apa lagi sih yang aku cari?

Ia pria yang baik, yang mencintaiku sepenuh hati. Bukankah seorang perempuan seperti aku membutuhkan hal itu. Bukankah pada akhirnya mudah bagiku mencintainya lagi dengan suka rela? Masa aku memilih menjadi Kunti dan Ayano-san? Ayano-san mungkin bahagia, ah tapi apa iya sih? Apa iya dia bahagia melepaskan Greg, suaminya dulu yang begitu baik dan mencintainya? Aku tidak pernah tahu pula. Yang jelas aku tidak mau hidup sendiri seperti Kunti, Jane, atau bahkan meninggal di pelataran parker seperti Mak Umah dengan jasad yang tidak diperlakukan semestinya...."

"Ya, syukur. Jangan jadi istri durhaka" (A, 2003: 269). 


\section{Kekerasan dalam Keluarga Dari Sudut Pandang Feminis}

Kekerasan dalam keluarga adalah implikasi dari ideologi jender. Hampir semua bentuk kekerasan dalam keluarga dilakukan oleh laki-laki. Budaya garis keturunan laki-laki dalam keluarga ternyata mempunyai ekses-ekses yang menimbulkan tekanan-tekanan di masyarakat. Hal ini tertuang dalam budaya laki-laki yang diberi kekuasaan dan menyalahgunakan kekuasaan tersebut. Seharusnya, dalam keluarga terjadi pembagian kekuasaan dan kesempatan yang sesuai dengan kemampuan pribadi, bukan melakukan penindasan dan penjajahan sehingga menimbulkan bias jender. Agar proses sadar jender terwujud, maka situasi ini harus dirubah. Untuk gambaran kekerasan dalam keluarga dari sudut pandang feminis dapat dilihat pada kutipankutipan berikut:

Aku hanya mengangguk-angguk saja. Temanku yang lain, Kunti juga telah membuktikan kata-kata yamh dilontarkan Ayano-san. Buktinya, setelah lebih dari tiga tahun disiksa fisik serta batinnya oleh si suami, akhirnya pada suatu malam Kunti melarikan diri. Berbekal uang pinjaman dari temannya, Ia Kembali ke Bombay. Terakhir Ia mengirimiku surat, orang tuanya menerimanya dengan tangan terbuka karena melihat tangannnya yang melepuh di sana sini. Kini, Kunti bekerja sebagai tenaga administrasi di New Delhi. Sayangnya, Ia tidak pernah bercerai. Mertuanya tidak mengizinkan dan Kunti tidak punya nyali untuk berperang mulut (A, 2003: 75).

Ideologi bias jender yang lain adalah perlakukan kekerasan suami Mak Umah. Untuk melukiskan tokoh June yang peduli dengan nasib yang menimpa Mak Umah diperlihatkan gambaran tokoh June yang menangis melihat kondisi kehidupan yang dialami Mak Umah, seperti terdapat pada kutipan berikut:

Ooo, rupanya dulu suaminya memukulnya. Seperti Kunti, temanku dulu. Bedanya, Mak Umah sudah serung menerimanya. Dari kecil ayahnya memukulnya. Karena itu ia kawin muda dengan penuda kampungnya, Osmat, dengan harapan nasibnya akan lebih bagus. Ternyata setelah menikah dan mengikuti Osmat, nasibnya seperti melompat dari sarang harimau ke sarang buaya, sama saja.

Aku menitikkan air mata. Dua ruangan kecil nan sumpek ini. Hanya ada Kasur tipis, lemari baju kecil, dan satu kursi (A, 2003: 264).

Selanjutnya, persoalan kekerasan dalam keluarga dari sudut pandang feminis terungkap melalui pembicaraan June dan Jane. June merasa Jane telah memngingatkannya untuk menghindari jalan berkelok yang dilakukannya terhadap rumah tangganya. June nyaris menangis tersedu-sedu. Jane lalu mengungkapkan bahwa kekerasan yang mencerminkan ideologi bias jender yang terjadi di dalam rumah tangganya membuat Jane meninggalkan suaminya. Hal ini terdapat pada kutipan berikut:

"June, dengar! Artinya kamu memilih Jigme karena ketenangan jiwa. Tidak apa-apa, June. Aku mengerti, terkadang, kita memilih pasangan bukan selalu karena dorongan seksual dan nafsu belaka..."

"Maksudmu?" sahutku.,

Jane bercerita. Sewaktu berusia delapan belas tahun dia masih tinggal di New Jersey dulu ia mempunyai pacar yang Bernama Cody. Sayangnya, Cody adalah pria yang kasar dan gemar memukul Jane. Jane yang tinggal seatap tanpa menikah dengan Cody lambat laun tidak tahan. Sehari bercinta, sehari kena duka. Selalu begitu. Akhirnya Jane melarikan diri, jauh hingga ke Boulder sini. Ia lkangsung dapat pekerjaan di Maplet Hill karena pintar masak. Ia lalu sempat menikah dengan pria lain bernama Shed, seorang tukang kayu. Namun pernikahan mereka Cuma bertahan selama satu tahun.

"Aku tidak bisa hidup tanpa cinta. Aku memikirkan Cody...” Isaknya lalu sayup mulai terdengar.

Aku jadi lebih termangu. Beberapa waktu lalu Jane memanduku untuk keluar dari jalan berkelok yang kulalui. Semenit yang lalu aku nyaris menangis tersedu-sedu, kini ia justru yang mulai tidak terbendung (A, 2003: 178).

Sementara itu, untuk melukiskan tokoh June yang perduli terhadap nasib sesama perempuan tergambar melalui percakapannya dengan Mak Umah, seorang perempuan tua pengumpul barang bekas. Dari hasil pembicaraan itu tergambar di benak June bahwa Mak Umah adalah seorang perempuan yang sering menerima perlakuan yang bias jemder dari suaminya berupa perlakuan kasar. Hal ini terdapat pada kutipan berikut:
"Mak dikasih MUIS (Majelis Ulama Islam Singapura) tiap bulan 'to," ujarnya seraya menjawab pertanyaan di benakku.
Aku mendengar banyak Yayasan di Singapura. Ada juga panti-panti jompo yang menampung orang tua yang sebatangkara seperti Mak Umah. Mengapa ia memilih tinggal sendiri?
"Mak tak mau ikut tinggal di panti jompo milik penerintah?" tanyaku hati-hati.
Ia terkekeh seperti biasa. "Tak payah. Mak tak suka 'to tinggal seatap dengan orang lain. Pasal nanti pukul-pukul Mak," jawabnya polos (A, 2003: 264).

Dari kutipan di atas jelaslah bahwa perlakuan kasar laki-laki terhadap kaum perempuan bukanlah suatu perilaku yanbg dapat menyelesaikan masalah, namun sebaliknya dapat menimnbulkan masalah baru yang dapat merugikan kaum perempuan. Dampaknya, dapat 
menjadikan kaum perempuan trauma dalam menghadapi kehidupan berumah tangga. Akhirnya, kaum perempuan yang sudah dihimpit dengan permasalahan-permasalahan berat dalam rumah tangga menjadi memikul beban yang berlipat ganda.

\section{SIMPULAN}

Berdasarkan pembahasan penelitian, maka dapat disimpulkan bahwa:

1. Kaum feminisme melarang keras poligami karena pada fakta sosial poligami membawa kemudaratan, terutama bagi perempuan. Selain itu, kenyataan menunjukkan bahwa banyak kaum laki-laki yang berpoligami tidak berlaku adil kepada istri sehingga menyebabkan kaum perempuan tersakiti. Hal ini beralasan karena adil tidak mungkin dapat dilaksanakan pada saat ini. Hal ini ditunjukkan oleh prilaku June yang sangat tidak menyetujui pernikahan abangnya Bowo bersama Putri sahabatnya

2. Bias jender pada kekerasan kaum laki-laki berakibat pada rasa trauma yang dialami oleh kaum perempuan untuk menikah kembali. Inilah yang dialami oleh perempuan Bernama Mak Umah. Kaum feminis menganggap kekerasan terhadap perempuan sebagai suatu ketentuan hukum yang harus dipertimbangkan sosial-kultural yang ada di masyarakat karena hukum untuk masyarakat, bukan masyarakat untuk hukum.

3. Kekerasan dalam rumah tangga adalah tindakan dalam rumah tangga baik oleh suami, istri, maupun anak yang berdampak buruk pada keutuhan fisik, psikis, dan keharmonisan hubungan dalam rumah tangga. Hal inilah yang dialami oleh tokoh perempuan Bernama Kunti sehingga ia lari meninggan rumah dan suaminya Kembali kepada orang tua. Tindakan kekerasan ini suatu hal yang tidak patut untuk ditiru dalam kehidupan sehari-hari. Seharusnya laki-laki dan perempuan memiliki pemahaman bahwa berbeda, tapi setara.

\section{Saran}

Berdasarkan hasil penelitian yang telah dilakukan, terdapat beberapa saran untuk dicermati dan ditindaklanjuti, antara lain:

1. Permasalahan yang timbul dalam hubungan sosial budaya melalui keluarga sebaiknya disikapi dengan bijak dan diarah dalam bentuk perlindungan. Contohnya dibuat perlindungan hukum dan masyarakat memahami bentuk perlindungan hukum yang ada.

2. Poligami harus ditempatkan sebagai bentuk perlindungan terhadap perempuan dan anak.

3. Keberagaman pendapat antara kaum laki-laki dan kaum perempuan harus disepakati secara bijak karena perbedaan dan persamaan pendapat merupakan sesuatu yang wajar.

\section{DAFTAR PUSTAKA}

Ahmad Baidawi. 2001. Gerakan Feminisme Dalam Islam, Jurnal Penelitian Agama (Yogyakarta: Pusat Penelitian UIN Yogyakarta), Vol. X, No. 2 Mei-Agustus

Danim, Sudarwan. (2002). Ancangan Metodologi, Presentasi, dan Publikasi Hasil Penelitian untuk Mahasiswa dan Peneliti Pemula Bidang Ilmu-ilmu Sosial, Pendidikan, dan Humaniora. Bandung: CV. Pustaka Setia.

Faqih, M. 2001. Analisis Gender dan Transpormasi Sosial. Yogyakarta: Pustaka Pelajar

Moleong, Lexy J. (2018). Metodologi Penelitian Kualitatif. Bandung: PT Remaja Rosdakarya.

Mosse, Julia Cleves. 1996. Gender Dan Pembangunan. Yogyakarta: Rifka Annisa Woman's Caris Centre dengan Pustaka Pelajar.

Kosasih, E. 2008. Apresiasi Sastra Indonesia. Jakarta: Perca.

Kosasih. E. 2012. Dasar-dasar Keterampilan Bersastra. Bandung: Yrama

Mufidah Ch. 2004. Paradigma Gender. Malang: Bayumedia Publishing.

Murniati, A. Nunuk P. 2004. Getar Gender, Perempuan Indonesia dalam Perspektif Sosial, Politik, Ekonomi, Hukum dan HAM, Buku Pertama. Magelang: Yayasan Indonesia Tera.

Puspitawati, H. 2012. Gender dan Keluarga: Konsep dan Realita di Indonesia. PT IPB Press. Bogor

Wicaksono, Andri. (2014). Pengkajian Prosa Fiksi. Yogyakarta: Garudhawaca.

Wolf, Naomi. 1994. Fire With Fire: The New Female Power and How to use It. New York: Vintage Books. 